\title{
HERPES ZOSTER AND ANGINA PECTORIS
}

\author{
BY \\ JOHN D. SPILLANE* AND PAUL D. WHITE
}

From the Massachusetts General Hospital, Boston, U.S.A.

Received May 18, 1939

Substernal pain on effort is recognized as one of the manifestations of disease of the coronary arteries. However, in recent years, clinicians have come to recognize the coronary nature of attacks in which pain is absent or minimal. That pain of cardiac origin is not necessarily paroxysmal has also been suggested, while occasionally painless sysmptoms have been recognized to accompany or even to replace true anginal pain. In a future paper the authors propose to describe such phenomena and consider their significance. In this communication we shall consider one such phenomenon, namely, herpes zoster, and its occurrence in patients with angina pectoris.

Several observers have noted the occurrence of herpes zoster in patients suffering from periodic bouts of anginal pain. A study of the case histories in Head's (1900) classical report on herpes zoster revealed that one of his patients was suffering from anginal paroxysms. He was a man of 35 years, with weakness and cough of two years' duration and severe attacks of pain over the heart. Herpes zoster developed over his chest on the right side, at the level Th. 7, one week before his entry to hospital. He died on the following day during a severe anginal attack and at autopsy proved to have extreme atheroma of the aorta, with aortic obstruction and regurgitation, and an enlarged left ventricle. No mention was made of the coronary arteries. The right Th. 7 ganglion was profoundly affected, riddled with extravasated blood and roundcell infiltration. Head did not consider the possible significance of the association of the two conditions. Osler, in his Lumleian lectures on angina pectoris (1910), mentioned a patient who developed herpes zoster along the track of the anginal pain he had felt periodically for the previous ten years ; it was the only such case that Osler had witnessed. Allbutt (1915) observed two cases in which the conditions were associated and wrote, "In the case of a lady (suffering from angina pectoris) who arrived at my house after an attack (of herpes zoster), the left arm had to be gently borne on a pillow by her maid as she passed from the carriage to the house."

With one exception, remaining references on this subject are of German origin. In Ortner's patient (1911) the zoster was distributed over the area subserved by the left ulnar nerve, Th. 1 ; such a distribution is uncommon

\footnotetext{
* Commonwealth Fund Fellow at Harvard Medical School, from the University of Wales.
} 
(Head, 1900). The patient had been suffering from genuine angina pectoris for some time and the pain radiated down the ulnar aspect of the left arm in attacks. Autopsy showed intense sclerosis of the coronary arteries without evidence of syphilis of the aorta or elsewhere. Fehsenfeld (1921) has described a similar case. Arnstein $(1921,1922)$ observed the association of herpes and angina, and in a paper entitled "Herpes zoster as the only manifestation of affections of internal organs running an otherwise latent course" concluded that zoster is frequent with disease of the lungs, liver, and kidneys, while rare with digestive, genital, and heart disease. He observed that its location usually corresponded with the organ affected. In one patient with marked sclerosis of the abdominal aorta attended with paroxysms of severe colicky abdominal pain, herpes zoster appeared over the left upper quadrant. Wertheimer (1927 and 1928) reported two patients with paroxysms of angina pectoris, of one and eight years' duration respectively, who developed herpes zoster over the area of radiation of substernal and arm pain. In one it occupied segments Th. 1-4 anteriorly and posteriorly on the left side, and segment Th. 1 on the left arm. In the second the arm was not involved by the rash, but the thumb and index finger of the left hand began to show diminished sensibility to pain. Parsonnet and Hyman (1930) have recorded three interesting cases in which recurrent attacks of herpes zoster were associated with the simultaneous development of symptoms and signs of progressive coronary disease, as evidenced by typical anginal seizures, electrocardiographic changes, and ultimate sudden death in all three. Previous to the first bouts of herpes zoster there were no cardiac symptoms or signs and electrocardiograms taken at the time of the herpes attacks proved normal.

We have encountered 12 instances of herpes zoster in a series of 350 patients with angina pectoris. In 10 instances the zoster appeared after the anginal attacks had become established, while in 2 the zoster preceded the angina. In the latter (Cases 11 and 12) the zoster first appeared before the first anginal paroxysm. In Case 11 the subsequent anginal pain involved the right shoulder and arm, where the zoster rash had appeared two and a half years before. In Case 12 there were recurrent attacks of herpes zoster over the left chest in the eighteen months preceding the first anginal attack. In the remaining 10 cases the anginal pains had been experienced first, in all but one for severai years, and in the majority were severe and frequent.

The main features of these 12 cases are outlined in Table I. The majority of patients were elderly, 8 being over sixty years of age. All suffered from true angina of effort, relieved by nitrites, except one (Case 10), who had a syphilitic aneurysm of the ascending limb of the arch of the aorta with much substernal and left arm pain. The Wassermann and/or the Hinton reactions were negative in the remainder, and none gave a history of luetic infection. Electrocardiograms, taken in six cases, all showed evidence of coronary insufficiency.

In Figs. 1 to 12 are outlined the distributions of the referred cardiac pain and herpetic eruption in the 12 patients, and short histories follow. In 10 cases a fairly close segmental relationship is apparent between the two areas. In 
Case 6 the cardiac pain was referred to the right shoulder and arm (C. 5, 6, 7, 8 and Th. 1, 2, 3) while the eruption appeared over the left shoulder (C. 4). In Case 9 the anginal pain was very severe and widespread; it radiated to both shoulders and arms and occasional paroxysms spread to involve the epigastrium, left upper quadrant of the abdomen and the left infrascapular region. The eruption commenced on the anterior aspect of the left thigh and spread upwards over the left inguinal and gluteal region to involve the left lumbar area (Th. 9, 10, 11, 12 and L. 1 and 2).

TABLE I

Herpes Zoster and Angina Pectoris

\begin{tabular}{|c|c|c|c|c|c|c|}
\hline $\begin{array}{c}\text { Case } \\
\text { Number }\end{array}$ & $\begin{array}{l}\text { Age in } \\
\text { Years }\end{array}$ & $\begin{array}{l}\text { Number of } \\
\text { Years with } \\
\text { Angina } \\
\text { before the } \\
\text { Onset of } \\
\text { Herpes }\end{array}$ & $\begin{array}{c}\text { Site of } \\
\text { Anginal Pain }\end{array}$ & $\begin{array}{c}\text { Severity of } \\
\text { Angina }\end{array}$ & $\begin{array}{l}\text { Frequency } \\
\text { of Angina }\end{array}$ & $\begin{array}{c}\text { Distribution } \\
\text { of Herpes }\end{array}$ \\
\hline 1 & 74 & 4 & $\begin{array}{l}\text { Substernal } \\
\text { to R. and } \\
\text { L. upper } \\
\text { chest }\end{array}$ & XXX & Daily & $\begin{array}{l}\text { Right : Th. 5, } \\
\text { 6,7. Anterior. }\end{array}$ \\
\hline 2 & 70 & 4 & $\begin{array}{l}\text { Præcordial } \\
\text { to L. } \\
\text { shoulder }\end{array}$ & XXX & $\begin{array}{l}\text { Irregular } \\
\text { Infrequent }\end{array}$ & $\begin{array}{l}\text { Left: Th. 2, 3, } \\
\text { 4. Anterior }\end{array}$ \\
\hline 3 & 67 & 6 & $\begin{array}{l}\text { Substernal } \\
\text { to L. chest } \\
\text { and } \\
\text { shoulder }\end{array}$ & $\mathrm{XX}$ & Frequent & $\begin{array}{l}\text { Left : Th. 2, 3, } \\
4 . \quad \text { Ant. and } \\
\text { Post. }\end{array}$ \\
\hline 4 & 60 & 2 & $\begin{array}{l}\text { Substernal } \\
\text { to R. chest }\end{array}$ & $X X$ & Frequent & $\begin{array}{l}\text { Right : Th. 6, } \\
7 \text {. Ant. and } \\
\text { Post. }\end{array}$ \\
\hline 5 & 54 & 5 & Substernal & $\mathrm{XX}$ & Frequent & $\begin{array}{r}\text { Left : Th. 5, } 6 . \\
\text { Ant. and Post. }\end{array}$ \\
\hline 6 & 83 & 12 & $\begin{array}{l}\text { Substernal } \\
\text { to } R \text {. arm }\end{array}$ & $\mathrm{XX}$ & Frequent & $\begin{array}{c}\text { Left : C. } 4 . \\
\text { Anterior. }\end{array}$ \\
\hline 7 & 70 & $1 / 2$ & $\begin{array}{l}\text { Substernal } \\
\text { to R. arm }\end{array}$ & $\mathrm{XXX}$ & Frequent & $\begin{array}{l}\text { Right : C. } 4 \text {, } \\
5 . \quad \text { Th. 1, } \\
3,4 . \\
\text { terior. }\end{array}$ \\
\hline 8 & 58 & 4 & Substernal & $\mathrm{XXX}$ & $\begin{array}{l}\text { Very } \\
\text { frequent }\end{array}$ & $\begin{array}{l}\text { Left : C. } 5,7 \text {, } \\
8 . \text { Th. } 1,2 . \\
\text { Anterior. }\end{array}$ \\
\hline 9 & 66 & 5 & $\begin{array}{l}\text { Substernal } \\
\text { to both } \\
\text { arms }\end{array}$ & $\mathrm{XXX}$ & $\begin{array}{l}\text { Very } \\
\text { frequent }\end{array}$ & $\begin{array}{l}\text { Left: Th. 9, 10, } \\
\text { 11, 12. L. 1, } \\
\text { 2. Anterior. }\end{array}$ \\
\hline 10 & 42 & 5 & $\begin{array}{l}\text { Substernal } \\
\text { to left } \\
\text { axilla and } \\
\text { neck }\end{array}$ & $\mathrm{XX}$ & $\begin{array}{l}\text { Very } \\
\text { frequent }\end{array}$ & $\begin{array}{c}\text { Left : C. } 4,5 \text {, } \\
6 . \text { Anterior. }\end{array}$ \\
\hline 11 & 49 & * & $\begin{array}{c}\text { Substernal } \\
\text { to R. arm }\end{array}$ & $\mathrm{XX}$ & Frequent & $\begin{array}{c}\text { Right : Th. } 4 \text {, } \\
5,6 . \\
\text { rior. }\end{array}$ \\
\hline 12 & 71 & * & $\begin{array}{l}\text { Substernal } \\
\text { to L. arm }\end{array}$ & $\mathrm{XX}$ & Frequent & $\begin{array}{l}\text { Left : Th. 4, 5, } \\
\text { 6. Anterior. }\end{array}$ \\
\hline \multicolumn{7}{|c|}{ XXX signifies severe anginal pain. } \\
\hline
\end{tabular}


Case 1.

\section{CASE Histories}

Male, aged 74. Left temporal headaches for five years. Four years dyspnœa on exertion and typical angina of effort, lasting a few minutes and relieved by rest or nitroglycerine. There was no actual radiation of the anginal pain to the left arm, but some numbness ; it spread to the upper chest on both sides, chiefly the right. About 8 months ago, when the angina was getting more frequent and severe, an herpetic eruption appeared over the right side of the chest anteriorly, Th. 5, 6 and 7 . Its lowest limit was at the costal margin approximately. He became more short of breath about this time. Three months later increasing dyspnœa and œdema of the ankles. For the past two months the anginal attacks have increased in frequency and severity.

Examination: Heart enlarged to the left by X-ray. Systolic thrill and systolic and probable diastolic apical murmurs. Radial and brachial arteries firm and tortuous. Blood pressure 160/85. Moderate œdema of ankles. Tortuous aorta by $\mathrm{X}$-ray. Electrocardiogram; rate 75 , fibrillating, inverted $\mathrm{T}$ waves in all leads, left bundle branch block.

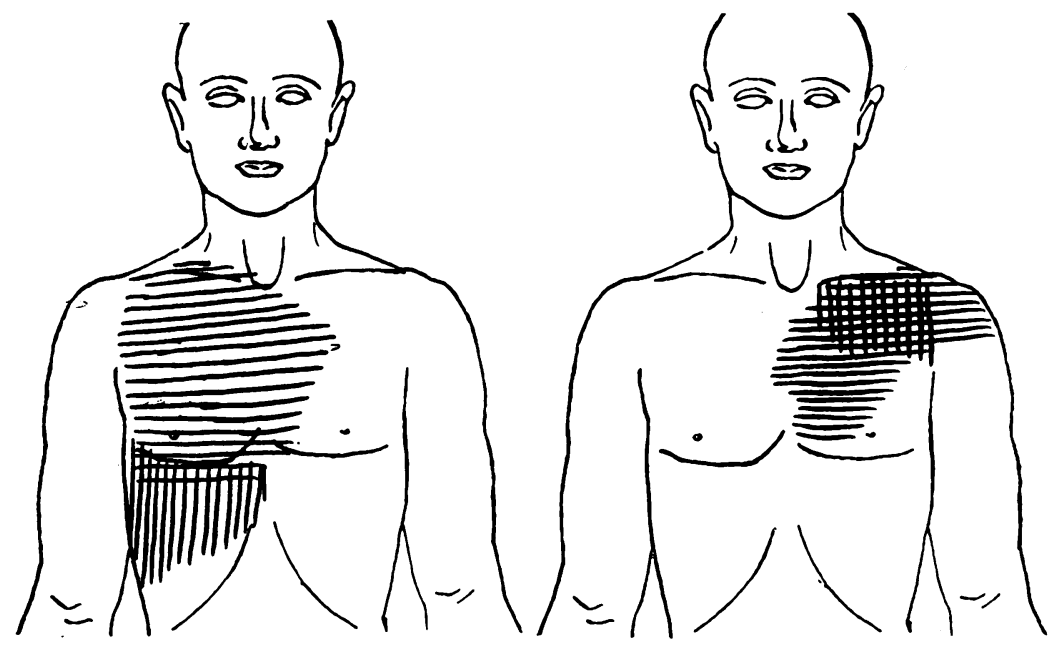

Case 1

Case 2

Figs. 1 and 2.-Diagram showing the areas of distribution of the herpetic eruption and of the referred cardiac pain. The black horizontal lines indicate the area of the referred pain and the vertical lines represent the distribution of the herpetic eruption.

Case 2.

Male, aged 70. Well and active until four years ago, when first attack of præcordial pain on walking. Tends to recur on excitement or exertion. One year ago a severe attack without radiation to arms. Hypertension then present. Two months ago herpes zoster over the left chest and shoulder. Unable to continue his work as a butler thereafter.

Examination : B. P. 180/90. Slight apical systolic murmur ; soft arteries ; liver edge felt one finger below costal margin ; slight œedema of ankles.

Case 3.

Male, aged 67. Six years headaches, palpitation, and weakness, and started to have dyspnœa and substernal distress on exertion : unable to walk any distance because of this. Three days ago severe persistent pain over left chest and shoulder, without 
radiation to arm. Substernal distress on exertion was particularly marked and lasted ten minutes at a time.

Examination: Obese, moderate peripheral arteriosclerosis, heart enlarged to the left with a forcible apex beat. B. P. 215/145. Systolic apical murmur. Herpetic lesions in left axilla and over upper three left ribs anteriorly, and posteriorly over left scapula. Urine, albumen and granular casts.

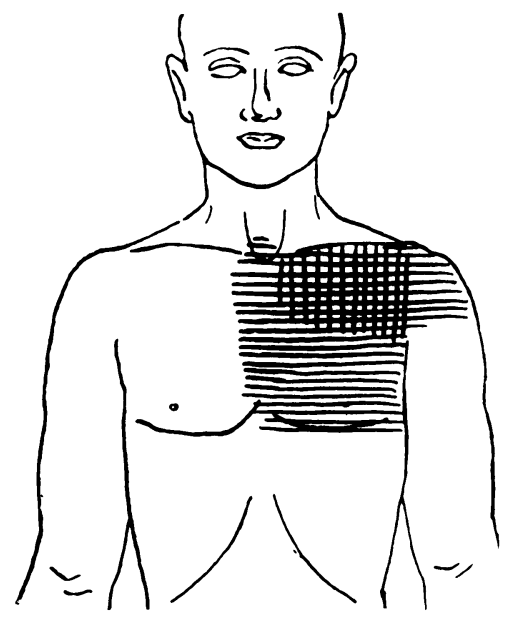

Case 3

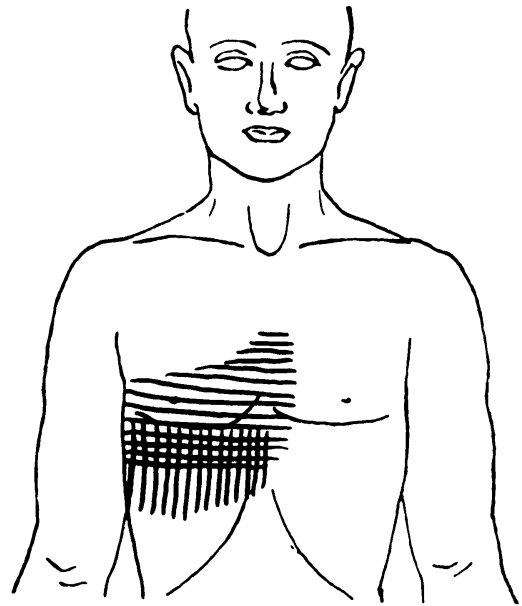

Case 4

FIGS. 3 and 4.-The black horizontal lines indicate the area of the referred pain and the vertical lines represent the distribution of the herpetic eruption.

\section{Case 4.}

Female, aged 60. Two years dyspnœa and occasional substernal pain on exertion. Two days ago sudden pain starting in the right costal margin and lower chest, radiating to the right costovertebral region. This pain persisted until admission to hospital.

Examination: Slight cyanosis. B. P. 160/70. Heart enlarged to left. Systolic and diastolic aortic murmurs. Wassermann negative. Electrocardiogram ; left axis deviation, sagging $T_{1}$ and $T_{2}$, slight late inversion of $T_{4}$, wide slurred $Q R S$ waves, deep $\mathrm{Q}_{4}$, high $\mathrm{S}-\mathrm{T}_{4}$. Herpes zoster over the area of pain. The patient improved, but returned one year later with persistent angina. A third admission to hospital ten years later with moderate cardiac failure and severe anginal episodes.

\section{Case 5.}

Female, aged 54. Five years ago frontal headaches and hypertension discovered. About the same time began to have substernal constriction on exertion. No radiation of pain to the arms. Attacks have persisted without much change. Five days ago superficial pain under the heart and round to the back, persistent and not in paroxysms as the anginal pain.

Examination: B. P. 260/120. Moderate arteriosclerosis. Heart enlarged to left. Blowing systolic præcordial murmur. Typical herpes over left præcordial region and at angle of left scapula. Hyperæsthetic.

\section{Case 6.}

Female, aged 83. Twelve years ago at the age of 71 severe pain in right upper chest, shoulder, and right arm on exertion. One year ago weakness and dizziness on exertion became prominent; no precordial pain at this time. Three days ago a typical herpes appeared over left shoulder. 
Examination : Marked arteriosclerosis. B. P. 180/100. Heart enlarged to left. Apical systolic murmur. Herpetic eruption.

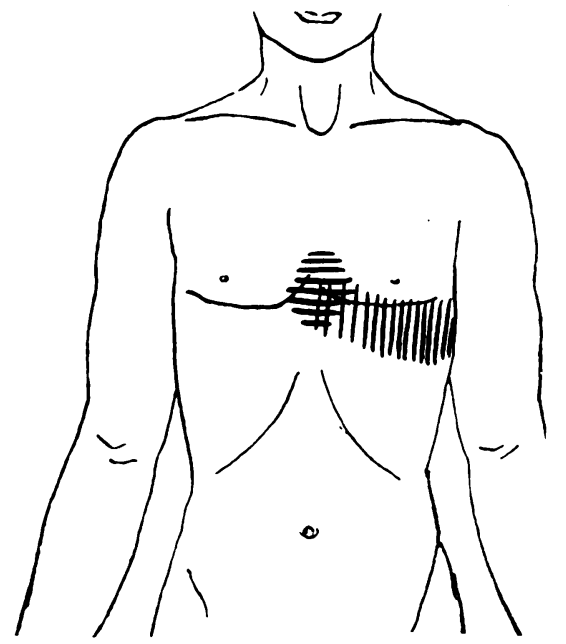

Case 5

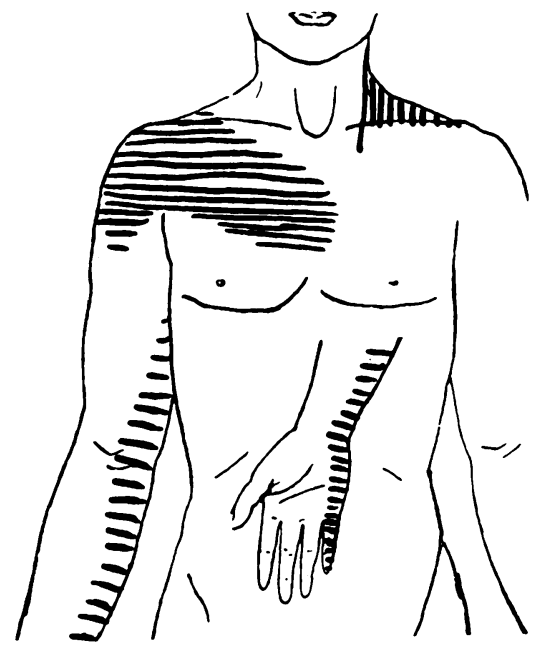

Case 6

FIGS. 5 and 6.-The black horizontal lines indicate the area of the referred pain, and the vertical lines represent the distribution of the herpetic eruption.

Case 7.

Male, aged 70. One and a half years dyspnœa on exertion with discomfort and exhaustion ; angina pectoris diagnosed, and attacks relieved by nitroglycerine. One

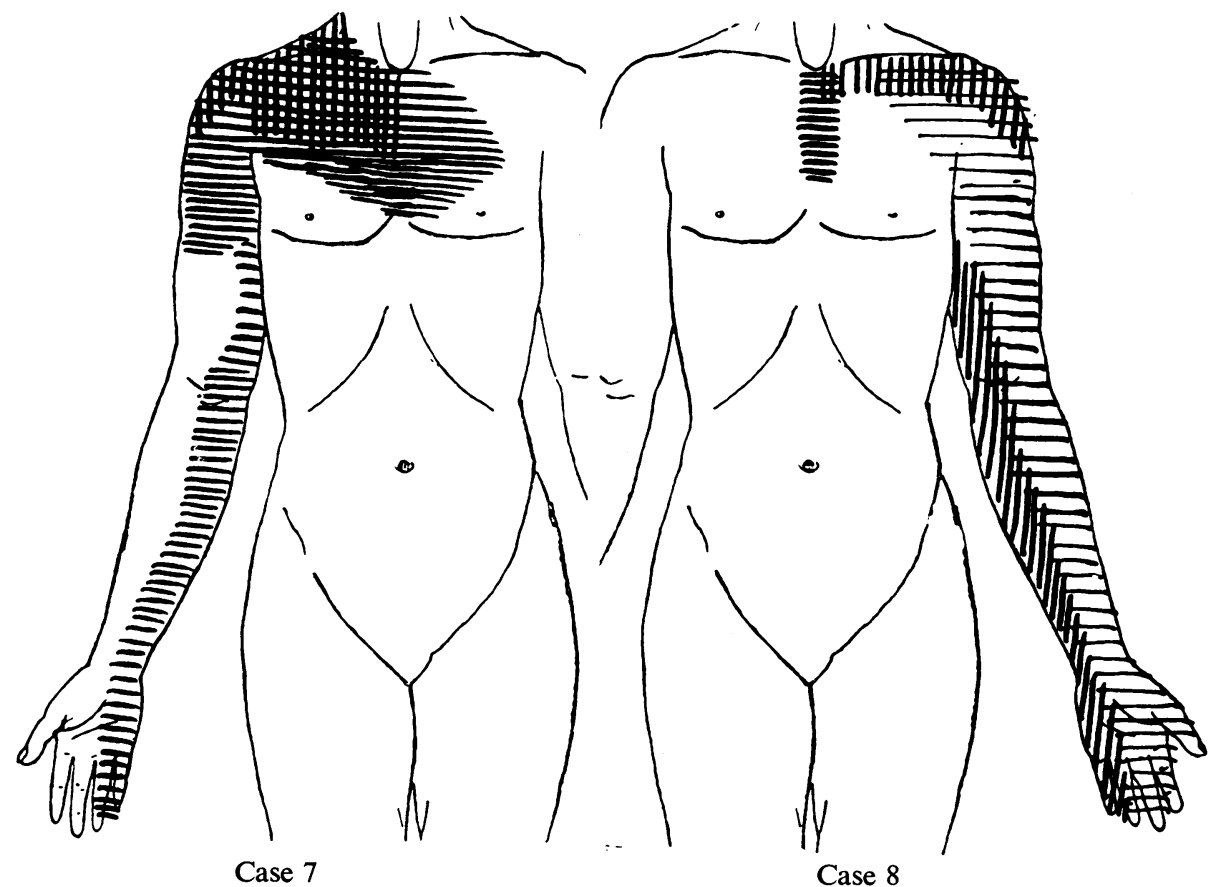

FIGS. 7 and 8.-The black horizontal lines indicate the area of the referred pain, and the vertical lines represent the distribution of the herpetic eruption. 
year ago herpes zoster over right arm, upper chest, shoulder, and neck ; still gets pain there at times, especially when resting. Six months ago typical anginal attacks with radiation of pain to the right shoulder and arm.

Examination: Poor, distant, heart sounds. Apical systolic murmur. Sclerosed radial artery. Rales at both lung bases ; liver edge tender, two fingersbreadth below costal margin ; no œdema.

Case 8.

Male, aged 58. Four years ago midsternal pain on exertion, relieved by rest, or nitroglycerine. Increasing in frequency and severity. Three years ago in hospital : heart enlarged to left, with distant heart sounds. Rough apical systolic murmur with (?) diastolic aortic murmur. Liver just palpable. Electrocardiogram; normal rhythm, low $T_{3}$, inverted $T_{4}$. Fairly well for the next three years. Last three months angina pectoris much worse, but still relieved by nitroglycerine. Two weeks ago more severe pain in left shoulder, radiating to the left arm and fingers. At first only present on exercise but soon became constant. Nitroglycerine ineffective. At this time the substernal anginal pain on exertion radiated to the left arm and left fingers, for the first time. No dyspnœa.

Examination: As before. B. P. 180/90. Typical herpes scattered over left shoulder and down the inner side of left arm to fingers. The painful area radiating from the sternum spread down the outer side of that arm. Gradual improvement.

Case 9.

Male, aged 66. Five years typical anginal attacks ; pain severe and widespread, to both arms, to epigastrium and left loin. Nitroglycerine gave prompt relief.

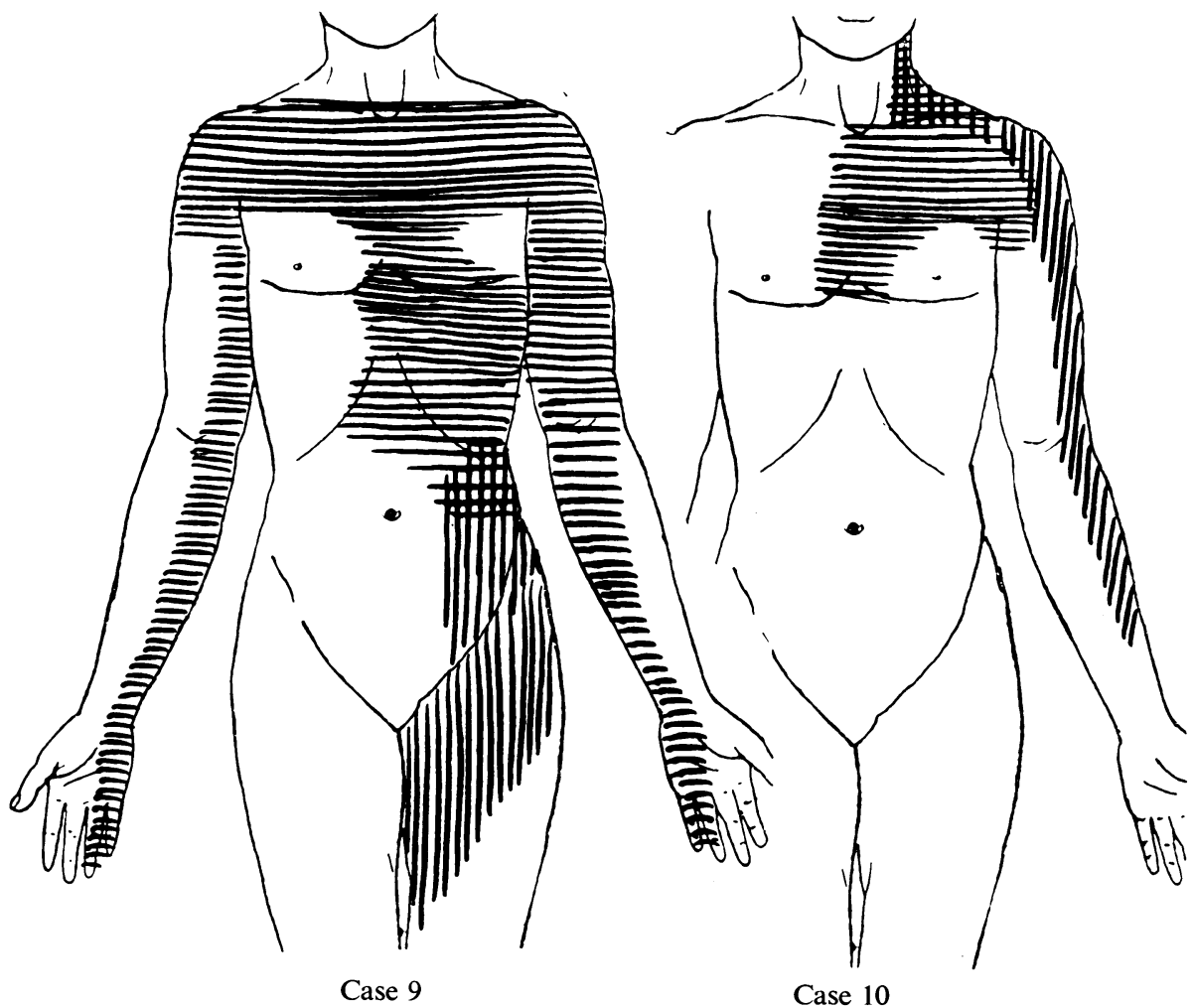

FIGS. 9 and 10.-The black horizontal lines indicate the area of the referred pain and the vertical lines represent the distribution of the herpetic eruption. 
Typical gout for some years. Four days ago sudden sharp shooting pain in left side of lower chest, loin, and left thigh. This was quickly followed by an herpetic eruption.

Examination: Obese. Herpes as described. Heart enlarged to left ; premature beats; apical systolic murmur. Moderate arteriosclerosis. Electrocardiogram; diphasic $\mathrm{T}_{1}$.

Case 10.

Male, aged 42. Five years præcordial pain with cough, dyspnœa, and dysphagia. Wassermann reaction positive. Aneurysm of aorta on X-ray. Treated with mercury and iodides. Now almost constant chest pain and anginal exacerbations. Aneurysm pointing in the suprasternal area. Two weeks ago hyperæsthesia over the left upper chest with severe, sharp, burning pain. Five days ago herpes zoster over left upper chest, axilla, and radial aspect of left arm.

\section{Case 11.}

Male, aged 49. Four years ago attack of herpes zoster involving the right chest and arm ; no sequelæ. Eighteen months ago some stabbing pain in left chest. Six months ago typical angina with pain down right arm. Attacks progressive and excruciating and one lasted for 36 hours.

Examination: Raised temperature and leucocytosis of 14,000. B. P. 115/70. Electrocardiogram; inverted $\mathrm{T}_{1}$ and $\mathrm{T}_{4}$, wide slurred QRS waves. Following this myocardial infarction, recurrent anginal attacks. Heart slightly enlarged.

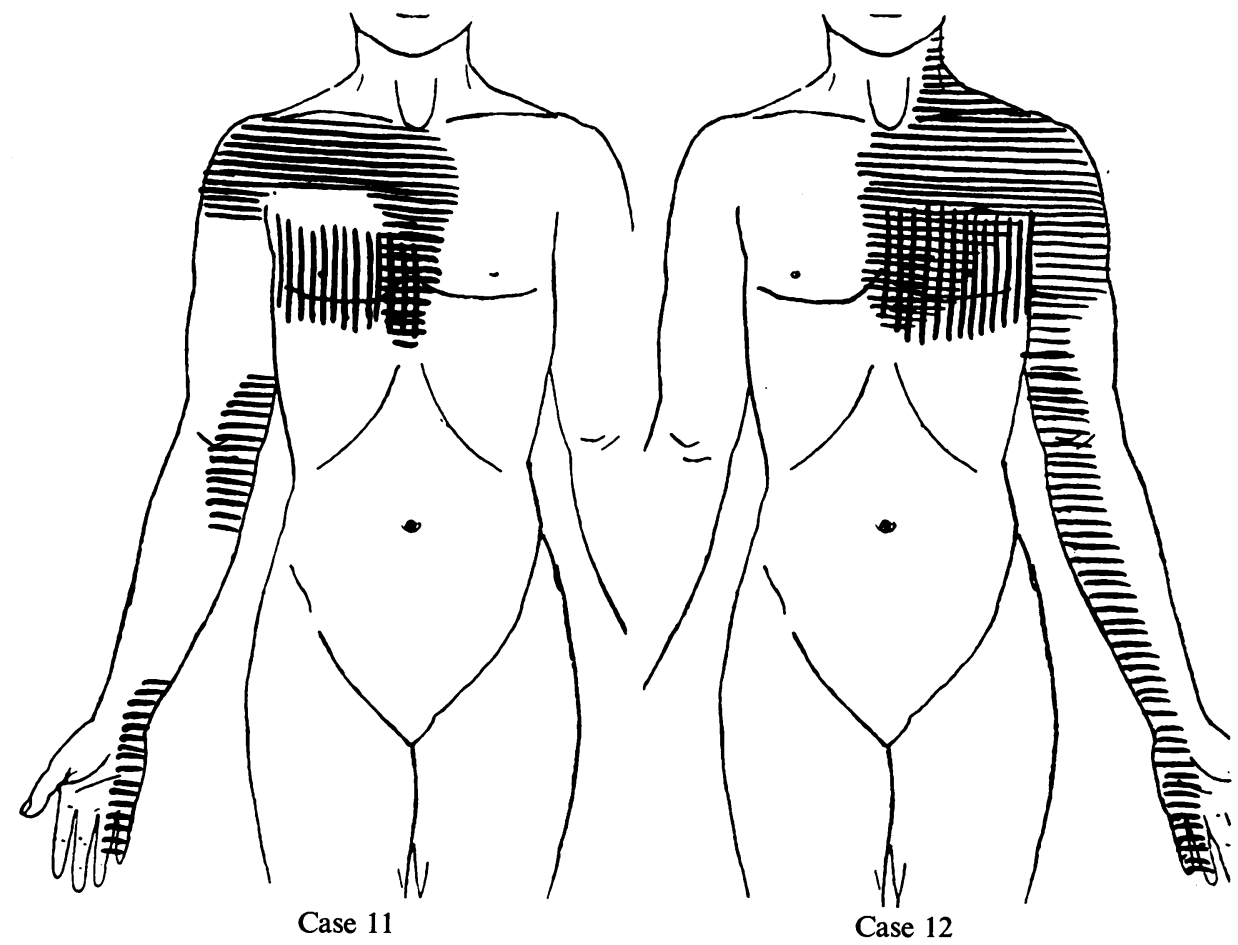

FIGS. 11 and 12.-The black horizontal lines indicate the area of the referred pain and the vertical lines represent the distribution of the herpetic eruption.

\section{Case 12.}

Male, aged 71. Recurrent attacks of herpes zoster over the left mid-chest region, front and back, during several years ; scars present under the left breast. Typical 
attacks of angina pectoris for eighteen months beginning substernally and spreading to left upper chest, shoulder, and ulnar aspect of left arm. Attacks provoked by exercise, emotion, or a heavy meal ; four or five attacks daily of late.

Examination: Moderate peripheral arteriosclerosis. B. P. 160/100. Heart enlarged to left, fair heart sounds, no murmurs. Palpable liver edge. Tortuous aorta on X-ray examination. Electrocardiogram ; diphasic $\mathrm{T}_{2}$ and $\mathrm{T}_{3}$.

\section{Discussion}

Are these findings fortuitous or does the zoster reflect some change in the posterior root ganglia in anginal patients? Having sifted the available evidence we lean to the latter explanation and suggest that the zoster is a trophic manifestation of continued irritation of the posterior root ganglia by impulses from the diseased viscus. Our evidence may be marshalled as follows.

As we have pointed out, the phenomenon has been recorded previously. The discovery of twelve examples among our own records is significant. A rapid control perusal of a large number of case histories of congestive heart failure revealed no example of herpes zoster in the same age group. The similarity between the relative areas of distribution of the referred cardiac pain and the herpetic rash is so striking in several instances that coincidence seems highly improbable. In Case 7 (Fig. 7) both were distributed over the right upper chest and inner aspect of the right arm. As pointed out by Head, herpes zoster only rarely involves the upper limbs.

Secondly, several reports have been published of the appearance of herpes zoster over the distribution of referred pain in other diseased conditions. Moreover, pain was an outstanding feature in all these, viz. biliary colic, renal colic, abdominal colic, pleurisy, pericarditis, appendicitis, and arthritis. Curtain (1902) has observed the appearance of herpetic eruptions over an acute arthritic knee joint, over the area of pain and friction in a dry pleurisy, over an area of localized peritonitis, and over the left kidney during a bout of hæmaturia. Bittorf (1911), Rosenbaum (1911), Kanera (1911), Rosenberg (1911), and Krotoszymer (1911) have described instances of the appearance of herpes zoster over the homolateral segments, Th. 10 or Th. 10 and 11, in cases of renal colic due to calculus or intermittent hydronephrosis. Severin (1926) observed two similar cases and one in which the herpes rash appeared over segment Th. 9 on the right side in a case of gallstone colic. In patients suffering from gastric colic with hypermotility of the stomach observed by fluoroscopy, Hess and Faltitschek (1925) described the appearance of herpes zoster over the lower thoracic segments. The gastric disturbances disappeared with the subsidence of the eruption. Lastly, Loeper and Loisel (1937) reported the occurrence of herpes zoster over the area of referred pain (C. 4, Th. 1 and 2) in acute rheumatic pericarditis. On the ninth day of an attack of acute rheumatism their patient, who was suffering from pericarditis, with a friction rub, developed an herpetic eruption, which disappeared with the exhibition of salicylates and the subsidence of the pericarditis.

The crises of pain in tabes dorsalis are sometimes attended by the develop- 
ment of herpes zoster. In recurrent gastric crises the zoster may make its appearance along the costal margin (Udaondo, 1928 ; Laignel-Lavastine and Boquien, 1932) and may appear over the legs following paroxysms of lightning pains. The known involvement of the root ganglia in this disease probably accounts for such phenomena, and may have been the reason for the outbreak of herpes zoster in our example with a syphilitic aneurysm (Case 10).

Thirdly, our contention gains support when it is recalled that other skin lesions have been observed along the line of radiation of pain in angina pectoris. Mackenzie (1893) recorded a case in which, following a series of rapidly recurring anginal attacks with radiation of pain down the left arm, a streak of ecchymoses, six inches in length, developed on the left arm without obvious cause, and was assumed to be trophic. That such a lesion probably resulted from disturbance in the thoracic posterior root ganglia is suggested by the known occurrence of similar ecchymotic areas along the path of the lightning pains of tabes dorsalis ; in the latter condition we know these ganglia are involved. Allbutt (1915) quoted two patients described by Gasne and Chiray (1905) ; both suffered from typical angina pectoris and both developed a peculiar rash resembling lichen planus along the areas of referred pain. In both it spread along the ulnar aspects of arm and forearm, and in one it involved the left chest wall also.

Admitting for the moment, then, that the appearance of the herpes zoster is in some way related to the second pathological condition present, viz.; disease of the coronary arteries, we may consider by what possible mechanism this can be brought about. Herpes zoster may be due to invasion of the posterior root ganglia by a specific virus, and involvement of the ganglia by adjacent disease processes can produce the condition. Leucæmic infiltration, Hodgkin's disease, tumours, and syphilis may act in such a manner. It is perhaps not widely known, however, that there is evidence that it may result in a reflex manner following repeated irritation of the ganglia by impulses from a diseased viscus. Head and Campbell (1900) wrote "the trophic disturbance of the skin is an extreme form of activity of the same cells, disturbance of which by afferent impulses along the white ramus produces the hyperalgesia that accompanies visceral and referred pain. ... The eruption is due to intense irritation of cells in the ganglion which normally subserve the function of pain, and more particularly that form of pain produced by afferent visceral impulses. . . . Some ganglia seem more prone to attack than others. . . . the ganglia most commonly affected are those which receive afferent impulses from the viscera."

Gaule (1894) was among the first to produce trophic changes in the skin of experimental animals by stimulation of the ganglia. He especially noted that these trophic effects were by no means confined to the segment served by the stimulated ganglion, but spread to the opposite side and over the whole body. This is of interest in view of our findings in some cases that the herpes may appear in adjacent segments, or even, as in Case 6, on the opposite side.

Krogh (1924) during his investigations on the physiology of human capillaries wrote " In herpes zoster we have evidence that a large number of capillaries 
... are in direct connection with posterior root fibres and become dilated when these are stimulated . . . by pathological processes."

Lewis and Marvin (1927), in like vein, concluded that the probable explanation for herpes zoster was that antidromic impulses released a histamine-like substance in the skin area of that segment, with capillary dilatation and blister formation. They suggested the mechanism was thus a modified triple response ; the period of stimulation is prolonged and the wheal is replaced by a blister.

For these reasons, then-the repeated clinical observation of herpes zoster in anginal patients, the analogy of the herpetic eruption in other painful visceral states, the occurrence of other skin lesions along the line of radiation of anginal pain, and the existence of an anatomical nervous pathway between ganglion and skin that can conduct antidromic impulses-it is reasonable to conclude that the appearance of herpes zoster over the area of referred pain in anginal patients is not fortuitous. It signifies the repeated bombardment of spinal root ganglia of the thoracic cord by afferent impulses from the diseased heart.

\section{Summary AND Conclusions}

We have described twelve instances of the occurrence of herpes zoster in anginal subjects. In ten of these the zoster appeared after the anginal attacks had become established. In two the zoster first appeared about two years before the first anginal paroxysm. In both these, as in the former group, a close association was apparent between the distribution of the herpetic eruption and that of the anginal pain.

Attention has been drawn to the occurrence of herpes zoster over the area of referred pain from other diseased viscera also, viz., the pleura, pericardium, gall bladder, kidneys, stomach, and appendix. We have suggested that repeated bombardment of spinal root ganglia by afferent impulses from the ischæmic heart gives rise to antidromic impulses that lead to vasodilatation and blister formation in referred cutaneous areas. The herpetic eruption is thus a trophic manifestation of disease of the coronary vessels in these cases.

\section{REFERENCES}

Allbutt, C. (1915). Diseases of the Arteries including Angina Pectoris. London, 2, 299. Arnstein, A. (1921). Wien. klin. Wschr., 34, 13. (1922). Wien. Arch. inn. Med., 4, 441.

- (1924). Med. Klinik, 20, 1485.

Bittorf, A. (1911). Dtsch. med. Wschr., 37, 290.

Boas, E. P., and Levy, H. (1937). Amer. Heart. J., 14, 540.

Curtain, R. G. (1902). Amer. J. med. Sci., 123, 264.

Fehsenfeld, G. (1921). Med. Klinik, 17, 783.

Gasne and Chiray (1905). Bull. Mém. Soc. méd. Hôp. Paris, 22, 296.

Gaule, J. (1894). Brain, 17, 223.

Head, H. (1893). Brain, 16, 1 .

- and Campbell, G. (1900). Brain, 23, 353.

Hess, H., and Faltitschek, J. (1925). Med. Klinik, 21, 1683.

(1931). Klin. Wschr., 10, 883.

Kanera, F. (1911). Dtsch. med. Wschr., 37, 668.

Krogh, A. (1924). The Anatomy and Physiology of Capillaries. London, 75.

Krotoszymer, M. (1911). J. Amer. med. Ass., 57, 900.

Laignel-Lavastine and Boquien (1932). Bull. Mém. Soc. méd. Hôp. Paris, 48, 116. 
Lewis, T., and Marvin, H. (1927). Heart, 14, 27.

Loeper, M., and Loisel, G. (1937). Presse méd., 45, 793.

Mackenzie, J. (1893). Brain, 16, 321.

(1913). Diseases of the Heart. London.

(1923). Angina Pectoris. London.

Ortner, N. (1911). Wien. klin. Wschr., 61, 1618.

Osler, W. (1910). Lancet, 1, 697.

Parsonnet, A. E., and Hyman, A. S. (1930). Ann. intern. Med., 3, 883.

Rosenbaum, A. (1911). Dtsch. med. Wschr., 37, 1120.

Rosenberg, E. (1911). Dtsch. med. Wschr., 37, 789.

Severin, J. (1926). Dtsch. med. Wschr., 52, 906.

Udaondo, C. B. (1928). Prensa méd. argent., 14, 941.

Wertheimer, R. (1927). Wien. klin. Wschr., 40, 623. (1928). Ibid., 41, 26. 